\title{
PHILOSOPHY
}

\section{ГЕРМЕНЕВТИЧНА ІНТЕРПРЕТАЦІЯ ЯК ПОРЯДОК ДИСКУРСУ}

\author{
Дубініна Віра Олександрівна, \\ Українська медична стоматологічна академія, завідувачка кафедри філософії та суспільних \\ наук, кандидат філософських наук, дочент, Україна \\ ORCID ID: http://orcid.org/0000-0001-8024-9823
}

DOI: https://doi.org/10.31435/rsglobal_ijitss/31052020/7054

\section{ARTICLE INFO}

Received 08 March 2020

Accepted 14 May 2020

Published 31 May 2020

\section{KEYWORDS}

hermeneutic, discourse order, understanding, interpretation, language, meaning, methodology. \begin{abstract}
The modern philosophical hermeneutics is considered in the context of ideas about the transformation of discursive practices and their influence on the formation of philosophical theories. Hermeneutics as a theory of understanding and interpretation itself acts as a family of discursive strategies, conditionally combined into a single whole and representing a new type of communication with the primary source of philosophical knowledge, which is especially important for understanding its individual components. The relationship of philosophical hermeneutics with the philosophy of language and the theoretical uncertainty of the most important elements of hermeneutic discourse are shown. In this article, we combine the idea of philosophical hermeneutics, as it developed in German philosophy of the XIX-XX centuries. with the notion that every philosophical theory, not to mention philosophical directions, develops, establishes a new, own order of discourse and that it is philosophical hermeneutics that is this new order that is somehow present in all directions of twentieth-century philosophy without exception: phenomenology, analytical philosophy, Marxism, psychoanalysis, etc. This interpretive discourse penetrates the flesh and blood of modern philosophy, being its quintessence and main motive.

One can imagine the space of interpretation as a certain common space of the collective unconscious in which each interpreter, as a dreamer, moves along its own path, i.e. this interpreter's dream is something larger, larger than what each of us sees in a dream. Then the figure of the coordinator, metainterpreter, moderator, standing above individual interpretations, arises or becomes in demand.

For all its ambiguity and vagueness of its theoretical foundations, philosophical hermeneutics undoubtedly seeks to constitute itself as a discursive norm, absorbing and subjugating all other speech practices. This allows us to talk about the hermeneutic paradigm of modern philosophy, the ideal of discourse, developing since antiquity and finding its embodiment and resolution in a wide range of modern philosophical theories. In a certain sense, one can speak of hermeneutics as a specific agent that penetrates into the very depths of interpretation schemes and methodologies. Perhaps this position of hermeneutics may cause criticism and suspicions of inescapable totality and peculiar repressiveness if the very nature of hermeneutic discourse did not contradict this point of view. Hermeneutics, by definition, opposes any violence against interpreted material, striving to reflect the whole spectrum of possible meanings and definitions.
\end{abstract}

Citation: Dubinina V. O. (2020) Hermeneutic Interpretation as a Discourse Order. International Journal of Innovative Technologies in Social Science. 4(25). doi: 10.31435/rsglobal_ijitss/31052020/7054

Copyright: (C) 2020 Dubinina V. O. This is an open-access article distributed under the terms of the Creative Commons Attribution License (CC BY). The use, distribution or reproduction in other forums is permitted, provided the original author(s) or licensor are credited and that the original publication in this journal is cited, in accordance with accepted academic practice. No use, distribution or reproduction is permitted which does not comply with these terms. 
Філософська герменевтика виступає як закономірна тематизація з боку мови і розуміння сенсу традиційних проблем європейської метафізики та продовження ії питань у сферу складної, багаторівневої структури смислу і смислової діяльності. Царина смислоіснування і смислопородження є своєрідною рецепцією класичної онтології, новим ï змістом і сенсом існування герменевтики як загально-філософської методології.

У наступній статті ми з'єднаємо уявлення про філософську герменевтику, яким воно склалося в німецькій філософії XIX-XX ст. 3 уявленням про те, що кожна філософська теорія, не кажучи вже про філософські напрямки, виробляє, встановлює новий, власний порядок дискурсу i що саме філософська герменевтика $\mathrm{i} \epsilon$ цей новий порядок, який так чи інакше присутній у всіх без винятку напрямках філософії XX століття: феноменології, аналітичної філософії, марксизмі, психоаналізі та ін. Цей інтерпретуючий дискурс проникає у плоть і кров сучасної філософії, іє іiі квінтесенцією і основним мотивом.

Дана проблема $\epsilon$ не просто одним 3 дослідницьких завдань, що стоять перед наукою, але виступає як сама суть, смислове ядро герменевтики. Можна сказати інакше: тотальність сенсу і ситуацій смислоутворення та інтерпретації є необхідними умовами конституювання герменевтичного дискурсу. При цьому сама герменевтика i $\epsilon$ порядок дискурсу, який встановлює основну теоретичну парадигму сучасності.

Тут можна згадати численні ситуації соціальної взаємодії, в яких затребуваний або просто передбачається герменевтичний дискурс. Можна говорити також про те, що скарги на брак розуміння настільки ж старі, як саме людство. В сучасних умовах, герменевтика як теорія і як система інтерпретаційних процедур і технік може розглядатися в якості підсумку розвитку всієї європейської філософії.

Таке уявлення про тотальності методу герменевтики було сформовано в німецькій філософії останніх двох століть і пов'язане з розвитком так званої нової герменевтики, теорії розуміння і інтерпретації, що вийшла за рамки традиційної богословської екзегези. Хоча $\mathrm{i}$ до теперішнього часу можна зустріти таке надзвичайно вузьке розуміння герменевтики і ії завдань.

На шляху перетворення герменевтики в універсальну теорію і методологію розуміння слід зазначити ряд ключових авторів і робіт, що зробили важливий внесок в даний процес. Найважливішою підставою для формування філософської герменевтики послугували роботи Г. Аста [5] i Ф. Шлейермахера [3], в яких вперше була поставлена задача побудови універсальної теорії інтерпретації. Визначальне значення в цьому процесі мали праці Вільгельма Дільтея, який вказав на особливу природу гуманітарного знання і його залежність від зусиль розуміння і інтерпретації. [Див. 1; 2]. Огляд даного етапу розвитку герменевтики можна знайти у відомій праці Г.Г. Шпета [4]. Найважливішим етапом розвитку герменевтичного дискурсу $є$ філософія М. Гайдеггера, серед ключових робіт якого традиційно відзначають його головну працю [9] і роботи більш пізнього періоду [напр. 10], нарешті, логічним підсумком розвитку німецької герменевтики виступають роботи Х-Г. Гадамера [6; 7; 8], що представляють собою своєрідний канон сучасної філософської герменевтики.

Герменевтика як царина інтерпретації водночас розвивалася в кількох напрямках, що дещо стримувало ії подальший розвиток. Бачення герменевтики як єдиної наукової теорії повинно було врахувати всі ці численні імпульси, які виходять від історичних шкіл, від філософії М. Гайдеггера і тих фундаментальних онтологічних питань, які він ставив на перше місце, а також від філологокритичного знання і того досвіду інтерпретації, який був накопичений класичної філологією.

Саме словосполучення «порядок дискурсу» (Ordre du discourse) традиційно розглядається як концепт філософії постмодерну, який вказує на соціокультурний i психологічний вимір дискурсивного середовища, тематизується в якості підсумку поширення і взаємодії деяких дискурсивних практик, тобто способів смислоуловлення i комунікації. Концепт представлений в однойменній роботі М. Фуко, яка присвячена аналізу механізмів контролю та детермінації в філософському і соціокультурному дискурсі. Фуко здійснює порівняльний аналіз дискурсивних практик, що культивуються в контексті сучасної культури, i дискурсивних практик класичної європейської традиції, що дозволяє йому визначити специфіку культурного статусу дискурсу i представити загальні закономірності соціокультурної детермінації останнього.

Описуючи смислові трансформації дискурсу, Фуко починає його історію з античності, в рамках якої дискурс належав до домінантних і привілейованих феноменів культурного 
простору. Подібний його статус був забезпечений загальними метафізично артикульованими підставами античної культури, які задають простір мислення, в рамках якого буття передбачалося пронизаним єдиним універсальним логосом, що осягаються в раціональному зусиллі. Дискурс, який конституювався в культурі подібного типу, не тільки сповіщав те, що має статися, але і сприяв його здійсненню, притягував і захоплював собою людей і вступав, таким чином, в змову з долею. Такий дискурс виявляється не тільки поширеним і впливовим, але й доволі небезпечним, оскільки володіє по відношенню до культурного простору актуальним потенціалом домінування, індивідуально представленому в соціально значущої для античного поліса фігурі філософа. В рамках античної філософії відбувається те, що позначається як велика платонівська відмінність, істина більш вже не полягала в тому, чим був дискурс, або в тому, що він здійснює, істина полягала тепер в тому, що він говорив, тобто істина перемістилася з акту висловлювання до того, що саме висловлюється - його змістом i формою, його об'єкту, його відношенню до свого сигніфікату.

Принциповим завданням герменевтики є розуміння і освоєння смислових горизонтів, які представлені в текстових або поза текстових формах. Тексти можуть бути написані природними мовами, а також на умовних текстах інших мистецтв. В певному сенсі текстом $\epsilon$ будь-який продукт цілеспрямованої людської діяльності - побут, архітектура, інші мистецтва і т. д. Саме герменевтика і $є$ способом розуміння та інтерпретації текстів, причому саме методологія роботи 3 текстами дозволяє створювати способи інтерпретації всіх інших соціально-культурних та історичних феноменів.

Також важливим підгрунтям герменевтики, тим що створює іiі можливість i ii необхідність $є$ існування зовнішнього та внутрішнього в слові, мови, знаку і т. і. Матеріальна форма знаку презентує його тільки 3 зовнішньої сторони. Ми розуміємо, що знак може виконувати свою функцію тільки при наявності того, що стоїть за його матеріальною формою, те що вважається поняттям сенсу. Саме існування цієї складової знаку і самої мови як знаку робить можливим герменевтичний дискурс.

Герменевтика мислиться як теорія, що встановлює визначення сенсу i смислоутворюючої діяльності. У зв'язку з цим виникають як мінімум два абсолютно нетривіальних питання. По-перше, що таке сенс і які можливі мінімальні носії сенсу. По-друге, яким чином сенс міститься там, де ми його вбачаємо?

Чи можливо однозначно казати про наявність сенсу, про презумпцію його існування. Існування де? В якому саме сегменті дискурсу ми прагнемо відшукати сенс того, що сказане або написане?

Що таке, це - там? І чому воно взагалі повинно бути? Можливо, нам просто хочеться, щоб сенс існував. Причому, сенс, як трансценденція. У звичному, іманентному ми перестаємо вбачати сенс, як не помічаємо повітря, яким дихаємо. Хоча, або трансценденція є у всьому, що пов'язане з людиною і ії життям, або про неї взагалі не варто казати. Це як з богом та іншими містичними сутностями. Якщо він не скрізь, то від нього можна сховатися, але тоді який же він всемогутній, якщо від нього можна сховатися?

Питання про співвідношення герменевтики як дискурсу і дискурсу про трансцендентне $\epsilon$ відкритим. Ми можемо розглядати його в різних версіях і наближеннях. Наприклад, можна говорити про відмінності в порядку дискурсу. Тобто в наявності дзеркальне співвідношення: онтологічний порядок ставить трансценденцію попереду інтерпретації, оскільки остання тому і можлива, що відшукує кордони пізнаваного і рухається уздовж них і за їх межі. Сама герменевтика тут виступає перш за все, як процедура, спосіб, органом, за допомогою якого відбувається зусилля інтерпретації, яка ніколи не досягає своєї кінцевої мети саме в силу замежності об'єкта, який підлягає інтерпретації. Подібне неодноразово відбувалося при спробах інтерпретації священних текстів, які за визначенням не можуть бути зрозумілими до кінця. Та й саме це «до кінця» також не може бути осмислене раціонально. Тут доречна аналогія зі спробою досягти обрію, але скільки б ми не рухалися, він завжди буде недосяжний.

Герменевтичний дискурс постійно стикається 3 якимось кордоном, неможливістю розуміння або, що цілком рівносильно, 3 можливістю практично будь-якого розуміння. Своєрідним аналогом даної ситуації $є$ знамениті антиномії Канта, до яких ми неминуче приходимо, коли починаємо використовувати свій розум не за його прямим призначенням. Дотримуючись цієї позиції, можна сказати, що герменевтична ситуація являє собою якусь п'яту 
антиномію або протиріччя, коли ми прагнемо відшукати сенс навіть там, де він за визначенням відсутній. Підстави для цієї презумпції сенсу слід шукати в самій організації нашої думки i, зрозуміло, у внераціональних мотивах людини. Сам Кант говорить про ці питання, як про такі, які ми просто приречені ставити. Так чи інакше, ми повинні відзначити, що герменевтичний дискурс і дискурс про трансцендентне не є такими, що суперечать один одному або збігаються в своїй основі. Скоріше, мова йде про перетин різних смислових регіонів, пунктом перетину яких і $є$ нескінченно умовний, постійно вислизаючий сенс.

Це складне становище безсумнівно можна вважати найважливішою апорією герменевтики, поряд з герменевтичним колом, а можливо, навіть більш важливим, оскільки т. зв. герменевтичне коло прекрасно перевтілюється при його збільшенні і перетворенні в систему кіл, в спіраль. У той же час, осягнення трансцендентного є віковічним завданням герменевтики, яка тільки й робить іiї можливою. Можна вказати на основні теоретичні позиції, які представляють наявність сенсу в інтерпретованих текстах:

1. Сенсу немає ні в чому. Перед нами простий, цілком традиційний нігілістичний варіант. Даний підхід виглядає абсолютно не продуктивно, бо так ми нічого не пояснюємо. Все одно потрібно зрозуміти, чому ми все ж вбачаємо сенс хоча б в деяких речах. Подібна загальність завжди приводить до своєю протилежності і як правило призводить до парадоксів.

2. Сенс $є$ в усьому. Незважаючи на життєствердне (платонівське) «так», проблеми ті ж, що і в першому випадку, потрібно пояснити, чому деякі речі позбавлені сенсу. Платонівська ідея бруду або сміття.

3. Сенс є в усьому, але по-різному. Тобто, один сенс більш осмислений, ніж інший. Існує більш-менш об'єктивна (попросту, загальна) градація сенсів, тому і здається, що якийнебудь маленький сенс вже і не сенс зовсім. Наводить на думку про можливість існування «найбільшого сенсу», чогось найголовнішого, найважливішого і т.п., що в кінцевому рахунку призводить все до того ж платонізму.

4. Сенс, який завгодно і в чому завгодно, $є$ чи ні, в залежності від установки інтерпретатора. Простий і добре вивчений релятивізм, з яким європейська філософія стикається 3 часу Протагора і його славнозвісного «людина $\epsilon$ міра всіх речей...». Наука прагне уникнути релятивізму через його мінімальну продуктивність, так, ми по-різному сприймаємо і розуміємо оточуючий світ, але при цьому ми зобов'язані якимось чином, пояснювати його непереборну єдність. Людина постійно виявляє цю єдність у всіх сферах своєї життєдіяльності, крім того, вона виявляє, що світ, яким вона його знає, виник задовго до ії народження і без ії свідомої участі.

5. У чому сенс просто $\epsilon$, а в чомусь його просто немає. Тут можливі варіанти релятивізму і дуалізму. Світло і темрява, гностики, Плерома тощо. Зрозуміло, що традиційно в матеріальних речах, об'єктах, матерії як такої сенсу не виявиться. Якщо щось і позбавляти змісту, то, звичайно, матерію. Тоді, якщо свідомість (в будь-якому істотному відношенні або в одній зі своїх суттєвих характеристик) виявиться раптом матеріальним, то воно буде позбавлене сенсу. Це дійсно так? Або все-таки навіть якщо дух і породжується матерією, то він все одно оперує смислами і сам є осмисленим. Тут ми опиняємося в області традиційних філософських спекуляцій, що становлять основу метафізичного дискурсу.

Можна уявити простір інтерпретації як якийсь загальний простір (місце) колективного несвідомого, в якому кожен інтерпретатор як якийсь сновидець рухається по власній траєкторії, тобто цей сон інтерпретатора $\epsilon$ щось більше, масштабніше, ніж те, що бачить уві сні кожен 3 нас. Тоді виникає або стає затребуваною фігура координатора, мета-інтерпретатора, модератора, який стоїть над індивідуальними інтерпретаціями. Ця фігура - умовність, просто тому, що її не існує. Тобто не існує в моїй ментальної активності. У всякому разі, про це не можна стверджувати нічого певного.

Можливо так само, що наші інтерпретації цілком автономні і прив'язані до чогось колективного лише зовнішнім, привхідним, випадковим чином. Але потім ця колективність не визначає чогось найважливішого в моїй свідомості. Тому інтерпретатором і координатором тут можу бути тільки я сам, або якась частина мене - сновидця. 3 цієї точки зору колективне несвідоме неможливо, як неможливий колективний головний біль.

Це дуже схоже на філософський зміст поняття інтенціональності. Хоча ми і не завжди розуміємо, що саме відображається в нашій інтерпретації, ми все ж таки можемо стверджувати, що будь-який ментальний феномен характеризується за допомогою того, що можна назвати 
внутрішнім існуванням предмета, його смисловим буттям, і що ми, хоча і в дещо двозначних виразах, назвали б ставленням до змісту, спрямованістю на об'єкт, під яким треба розуміти не тільки предметну дійсність, але також ментальну, іманентну смислову предметність. 3 даної точки зору кожна емоція, кожний пізнавальний акт містить в собі щось у якості об'єкту, хоча форми буття цих об’єктів можуть суттєво відрізнятись.

Філософська теорія, що виникла на базі феноменології розглядає концепт інтенціональності як тісно пов'язаний з фундаментальною герменевтичною проблематикою. Також надзвичайно гостро стоїть питання про інтенціональність у ставленні до власне ментальних феноменів, - свого роду наведеною, привхідною інтенціональністю. Щоб зрозуміти останню саме і треба створити саму філософську герменевтику, оскільки саме ментальна, суб'єктивна діяльність людини найбільш радикально протидіє науковому, об'єктивному пізнанню, саме наша суб'єктивність підлягає герменевтичному розумінню та інтерпретації. Саме тому інтенціональність $є$ найважливішою, принциповою характеристикою свідомості, саме вона виступає найбільш фундаментальною складовою герменевтики.

Майже кожна людина відчуває труднощі, коли хоче піддати герменевтичному аналізу весь цей фантазійний, суб'єктивний ряд. У той же час, це її особисті стани, що притаманні тільки їй і тільки вона може бути експертом в їх інтерпретації. Але ця вихідна інтерпретація не буває досить чіткою, вона потребую додаткових механізмів, послідовного проведення всіх етапів феноменологічної редукції для того, щоб віднайти смисл, як певний результат, а не починати з нього, як з надійного феноменологічного джерела. Якщо б люди так просто могли б казати, що їм відомо і миттєво, без зайвих зусиль знаходили сенс у своїх безпосередніх переживаннях, саме питання про необхідність герменевтичної інтерпретації було б зняте.

Таким чином, при всій своій неоднозначності, багатовимірності і розмитості своїх теоретичних засад, філософська герменевтика безсумнівно прагне конституюватися у якості дискурсивного нормативу, що вбирає в себе і підпорядковує собі всі інші мовні практики. Це дозволяе казати про герменевтичну парадигму сучасної філософії, ідеал дискурсу, що розвивається з часів античності і знаходить своє втілення і простір в широкому спектрі сучасних філософських теорій. У певному сенсі можна говорити про герменевтику як про специфічного агента, що проникає в самі надра інтерпретаційних схем та методологій. Можливо, такий стан герменевтики може викликати критику і підозри в невичерпній тотальності і своєрідної репресивності, якби сама природа герменевтического дискурсу не суперечила такому розумінню. Герменевтика за визначенням протистоїть будь-якому насильству над тим, що інтерпретується, прагнучи відобразити весь спектр можливих сенсів і визначень.

\section{ЛІТЕРАТУРА}

1. Дильтей В. Собр. соч. В 6 т. / В. Дильтей; Пер. с нем. под ред. В.С. Малахова. - М.: Дом интеллектуальной книги, 2000. - Т.І. - Введение в науки о духе. -768 с.

2. Дильтей В. Собр. соч. В 6 т. / В. Дильтей; Пер. с нем. под ред. В.С. Малахова. - М.: Дом интеллект. книги, 2001. - T. IV. - Герменевтика и теория литературы. - 536 с.

3. Шлейермахер Ф. Герменевтика [Текст] / Пер. с нем. А.Л. Вольского / Ф. Шлейермахер. - СПб.: Европейский Дом, 2004. - 242 с.

4. Шпет Г.Г. Герменевтика и ее проблемы // Шпет Г.Г. Мысль и слово. Избранные труды. - М.: РОССПЭН, 2005. - С. 248-469.

5. Ast G.W.F. Grundlinien der Grammatik, Hermeneutik und Kritik. Landshut, 1808. - 228 s.

6. Gadamer H.-G. Gesammelte Werke. Bd. 1. - Hermeneutik I. - Wahrheit und Methode. - Tübingen, 1990, $494 \mathrm{~s}$.

7. Gadamer H.-G. Text und Interpretation // Deutsche-Französische Debatte mit Beiträgen von J. Derrida, Ph. Forget, M. Frank, H.-G. Gadamer, J.Greisch und F. Laruelle / Hrsg. Philippe Forget. Wilhelm Fink Verlag, München 1984. - S. 24-55.

8. Gadamer H.-G. Gesammelte Werke. Bd. 7. - Plato im Dialog. - Tübingen, J. C. B. Mohr (Paul Siebeck), $1991,445 \mathrm{~s}$

9. Heidegger, M. Sein und Zeit. Neunzehnte Auflage. Tübingen, Max Niemeyer Verlag, 2006, 445 s.

10. Heidegger, M. Platons Lehre von der Wahrheit. Frankfurt am Main, Vittorio Klostermann, 1967. 